\section{AL-AZHAR Dental Journal}

F $\quad \mathrm{O} \quad \mathrm{r}$
The Official Publication of The Faculty of Dental Medicine For Girls, Al-Azhar University Cairo, Egypt.

\title{
Effect of Different Concentrations of Double Antibiotics used in Regenerative Endodontic on MicroHardness and Fracture Resistance of Radicular Dentin
}

\author{
Hadeer M. Mostafa ${ }^{1^{*}}$, Wael H. Kamel², Maha A. Elhosiny ${ }^{3}$
}

\begin{tabular}{|l|}
\hline Codex : 47/20.07 \\
azhardentj@azhar.edu.eg \\
http://adjg.journals.ekb.eg \\
\hline DOI: $10.21608 /$ adjg.2020.26113.1244 \\
\hline $\begin{array}{l}\text { Restorative Dentistry } \\
\text { (Removable Prosthodontics, Fixed } \\
\text { Prosthodontics, Endodontics, Dental } \\
\text { Biomaterials, Operative Dentistry) }\end{array}$ \\
\hline
\end{tabular}

\section{KEYWORDS}

Revascularization,

Double Antibiotic Paste,

MicroHardness, Fracture

Resistance.

\begin{abstract}
Purpose: to show the effect of different concentrations of double antibiotics paste (DAP) $1,0.1,0.01 \mathrm{mg} / \mathrm{ml}$ used in regenerative endodontic on microhardness and fracture resistance of radicular dentin. Material and methods: Forty single rooted teeth were prepared and randomized into three groups according to DAP concentration (10 samples each) and ten samples were availed as control group. Group I: root canal contained $1 \mathrm{mg} / \mathrm{ml}$ DAP. Group II: root canal contained $0.1 \mathrm{mg} / \mathrm{ml}$ DAP. Group III: root canal contained $0.01 \mathrm{mg} / \mathrm{ml}$ DAP. Samples were stored at $37{ }^{\circ} \mathrm{c}$ with $100 \%$ humidity for three weeks then DAP was removed by irrigation with $1.5 \% \mathrm{NaoCl}$ followed by 17 $\%$ EDTA, finally flushed with distilled water. After removal of DAP, each tooth was decoronated at the level $0.5 \mathrm{~mm}$ radicular to the facial cementoenamel junction with isomet saw under water cooling. Two root cylinders were attained, one cylinder for fracture resistance assessment and the other cylinder for microhardness assessment. Results: For microhardness test, there was a statistically significant difference among different concentrations of DAP $(\mathrm{P} \leq 0.05)$. The highest mean value of microhardness was recorded in group III (DAP $0.01 \mathrm{mg} / \mathrm{ml})$. For fracture resistance test, there was statistically significant difference among different concentration of DAP $(P \leq 0.05)$, group III (DAP $0.01 \mathrm{mg} / \mathrm{ml}$ ) showing the highest mean value of fracture resistance. However group III (DAP $0.01 \mathrm{mg} / \mathrm{ml}$ ) showing no significant difference with control group. Conclusion: Lower concentration of double antibiotic $(0.01 \mathrm{mg} / \mathrm{ml})$ increases microhardness and fracture resistance of radicular dentin in revascularization procedure.
\end{abstract}

- $\quad$ Paper extracted from Master thesis titled 'Effect of Different Concentrations of Double Antibiotic used in Regenerative Endodontic on Microhardness and Fracture Resistance of Radicular Dentin'

1. Dentist at Ministry of Health, Egypt.

2. Professor of Endodontic department Faculty of Dental Medicine for Girls Al-Azhar University, Cairo, Egypt.

3. Lecturer of Endodontic department Faculty of Dental Medicine for Girls AL-Azhar University, Cairo, Egypt..

* Corresponding author email: hadeermaher182@gmail.com 


\section{INTRODUCTION}

The advantage of endodontic therapy is to completely destroy bacteria that involved in endodontic infection and provide three dimensionally seal of root canal system. Endodontic treatment of nonvital teeth with incomplete apex is one of the most demanding treatments due to their slender, brittle and blunderbuss apices. Dental caries, trauma, and dental anomalies may lead to pulp necrosis of teeth with open apex due to the halt of root formation ${ }^{(1-3)}$. Artificial apical plug application by mineral trioxide aggregate (MTA) or Calcium hydroxide $\mathrm{Ca}(\mathrm{OH})_{2}$ Apexification are historically means of treating non vital teeth with open apex. But, this way needs more time to complete treatment and do not strength the weak and thin roots of teeth with open apex ${ }^{(4)}$. Pulp revascularization is used to treat non vital teeth with open apex. That allows the complete of root forming and enhances the result of non-vital teeth with open apex ${ }^{(5)}$.

Using intracanal medicaments help in disinfection of root canal ${ }^{(6)}$. Many materials have been used as intracanal medication, triple antibiotic paste TAP is the first choice as intracanal medicament that consists of flagyl, ciprocin and tetracycline ${ }^{(7)}$. Using TAP allow to kill microbes, but its disadvantage is crown discoloration due to presence of tetracycline $^{(8)}$, so double antibiotic paste DAP is used successfully in endodontic regeneration that composed of only flagyl and ciprocin to overcome this disadvantage. Using of DAP with higher concentration eradicate microbes but it has cytotoxic effect on viability of apical papilla stem cells and although affect physical characteristics, fracture resistance and microhardness of radicular dentin ${ }^{(9-10)}$, due to the presence of acid in some types of antibiotic that keep it stable chemically, control tonicity and ensure physiological compatibility. Lower concentration of DAP has significant effect on microbes and negative effect on viability of apical papilla stem cells ${ }^{(11)}$. The aim of this study was to investigate the effect of lower concentration of DAP $(1,0.1,0.01 \mathrm{mg} / \mathrm{ml})$ on microhardness and fracture resistance of radicular dentin of immature teeth.

\section{MATERIALS AND METHODS}

\section{Teeth selection and endodontic preparation:}

Forty extracted single sound rooted human teeth with straight roots, free of previous endodontic treatment and roots cracks were used for this study. Ethical agreement in the use of extracted human teeth was achieved in accordance with guidelines from Research Ethic Committee (REC) of faculty of Dental Medicine AL-AZhar University. The calculus were leaved out from the teeth with hand scaler, teeth were disinfected by immersion in $2.6 \%$ sodium hypochlorite for six hours and followed by storage in sterile saline to prevent bacterial growth until use.

Three millimeters of each root tip were removed by using Endo $\mathrm{Z}$ bur with water coolant at an angle of 90 degrees with the long axis of the root to remove the apex and standardize the canal exit to the center of the tooth. A conventional coronal access cavity preparation was performed by size 4 round bur and using k file \#15 as initial file, then shaping the canal with Pro Taper rotary instrument to size taper (F5) by using endodontic motor .To achieve simulation of teeth with open apex, pesso reamers between \#1 and \# 6 were entered in the root canals by using low speed motor and a \#6 pesso reamer was be allowed to protrude $1 \mathrm{~mm}$ beyond the apex to obtain the apical diameter $1.5 \mathrm{~mm}$. Irrigation was done using $3 \mathrm{ml}$ of $2.6 \%$ sodium hypochlorite after each instrument. Root canals were cleaned with saline as a final flush and using paper points for drying the canal.

\section{Preparation of double antibiotic paste and grouping the samples:}

To prepare different concentrations of DAP $500 \mathrm{mg}$ of antibiotic powder composed of equal portion of ciprofloxacin (Ciprocin $250 \mathrm{mg}$ ) and metronidazole (Flagyl $250 \mathrm{mg}$ ) were mixed with $100 \mathrm{ml}$ of distilled water, then put them on magnetic 
stirrer, after that the mix were put on centrifuge for $20 \mathrm{~min}$ at $30.000 \mathrm{rpm}$ to obtain the first concentration of DAP $(1 \mathrm{mg} / \mathrm{ml})$. Ten $\mathrm{ml}$ from this concentration $(1 \mathrm{mg} / \mathrm{ml})$ were mixed with $90 \mathrm{ml}$ distilled water to obtain the second concentration $(0.1 \mathrm{mg} / \mathrm{ml})$. For the last concentration $(0.01 \mathrm{mg} / \mathrm{ml}), 10 \mathrm{ml}$ of concentration $(0.1 \mathrm{mg} / \mathrm{ml})$ were mixed with $90 \mathrm{ml}$ purred water, $2.5 \mathrm{~g}$ of methyl cellulose powder was added to $100 \mathrm{ml}$ of each solution under magnetic stirring to attain a homogenous gel with different concentrations $(1,0.1,0.01 \mathrm{mg} / \mathrm{ml})$.

Forty samples were randomly divided in to three main groups (I, II, III) according to concentration of DAP each of 10 samples. Ten samples were served as untreated control group. Group I: root canal space filled with concentration $1 \mathrm{mg} / \mathrm{ml}$ of DAP, Group II: root canal space filled with concentration $0.1 \mathrm{mg} / \mathrm{ml}$ of DAP, Group III: root canal space filled with concentration of $0.01 \mathrm{mg} / \mathrm{ml}$ of DAP.

For each group, one $\mathrm{ml}$ of each concentration was injected into the canal using a sterile plastic syringe. The root canals of all treatment groups were sealed apically with flowable composite and the access openings were sealed with composite. The samples were stored at $37^{\circ} \mathrm{c}$ with $100 \%$ humidity for three weeks.

\section{Preparation of root specimens:}

After three weeks DAP was removed from each specimen by irrigation with $20 \mathrm{ml}$ of $1.5 \% \mathrm{NaOCl}$ for 5 minutes followed by $10 \mathrm{ml}$ of $17 \%$ EDTA for 5 minutes using - irrigating needle 31 gauge side vent. Finally root canal was flushed with $5 \mathrm{ml}$ distilled water for 2 minutes. After removal of DAP, each tooth was put on acrylic blocks then decoronated at the level $0.5 \mathrm{~mm}$ radicular to facial cementenamel junction with a low speed diamond saw Isomet 40000, BUEHLER. , Germany) under water cooling. Tow root cylinders were obtained from each tooth. $5 \mathrm{~mm}$ cervical for fracture resistance test and $3 \mathrm{~mm}$ apical for micro hardness test.

\section{Microhardness test:}

About $3 \mathrm{~mm}$ from apical part of root used for microhardness test by using Willson hardness test (BUEHLER, Germany) by making three indentions on each specimen using a $50 \mathrm{gm}$. load and 10 second dwell time. The indentations were measured using an optical microscope equipped with a digital camera and image analysis software. The representative hardness value for each specimen was obtained as the mean of the results from the three indentations.

\section{Fracture resistance test:}

About $5 \mathrm{~mm}$ from coronal part of root below the level of cemento-enamel junction used for fracture resistance test using Universal testing machine (Instron,USA) (fig1) by embedded this part in acrylic resin block at $45^{\circ}$ angle then allowed to polymerize for $1 \mathrm{~h}$. The blocks with vertically aligned specimen were mounted in the machine. Static loading force $(5 \mathrm{KN})$ was applied till fracture. Data were recorded using Nexygen computer software at a crosshead speed $1 \mathrm{~mm} / \mathrm{min}$. Failure manifested by audible crack sound and confirmed by sudden drop along load deflection curve recorded by Nexygen computer software.

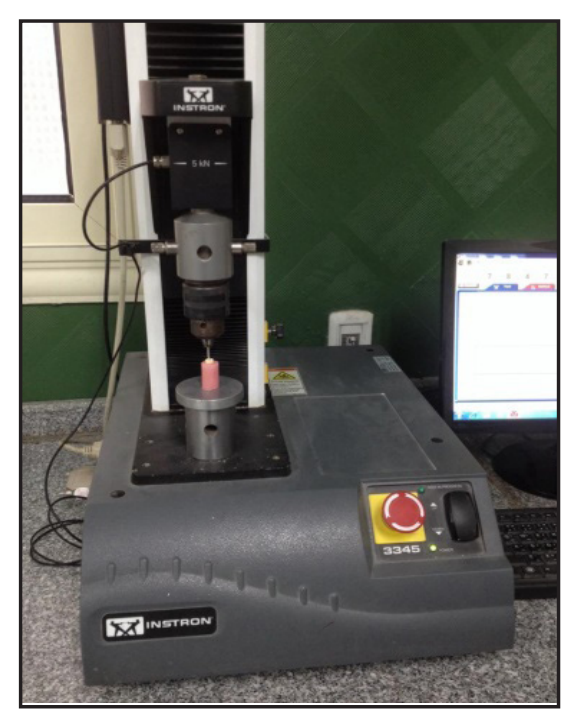

Figure (1): Showing instron machine. 


\section{Statistical analysis:}

Data collected were reviewed, coding and statistical analysis of collected data were done by using SPSS program (statistical package of social science; SPSS Inc., Chicago, IL, USA) . Mean and standard deviation were calculated to measure central tendency and dispersion of quantitative data. Comparing groups was done using :Analysis of variance ANOVA test to determine the significance in the difference between more than two means. Post hoc Tukey test was used when ANOVA test is significant to show between which group the significance difference present. The level of significance was taken at $\mathrm{p}$-value of $\leq 0.05$.

\section{RESULTS}

\section{Microhardness:}

ANOVA test showed that there was a statistically significant difference among different concentrations of DAP $(\mathrm{P} \leq 0.05)$. The highest mean value of microhardness was recorded in group III (DAP $0.01 \mathrm{mg} / \mathrm{ml}$ ). Post hoc Tukey test revealed that group I (DAP $1 \mathrm{mg} / \mathrm{ml}$ ) \& group II (DAP $0.1 \mathrm{mg}$ / $\mathrm{ml}$ ) were showing statistically signficant difference with control group however group III (DAP $0.01 \mathrm{mg}$ / $\mathrm{ml}$ ) showing no statistically signficant difference with control group as showing Table (1) \& (Fig 2).

Table (1): Descriptive analysis of the microhardness among the studied groups.

\begin{tabular}{|c|c|c|c|c|c|}
\hline $\begin{array}{c}\text { Statistical Groups } \\
\text { parameters }\end{array}$ & $\begin{array}{c}\text { Group I } \\
(1 \mathrm{mg})\end{array}$ & $\begin{array}{c}\text { Group II } \\
(0.1 \mathrm{mg})\end{array}$ & $\begin{array}{c}\text { Group III } \\
(0.01 \mathrm{mg})\end{array}$ & Control group & Significance test \\
\cline { 1 - 5 } Mean & $50.25^{\mathrm{a}}$ & $56.68^{\mathrm{b}}$ & $67.85^{\mathrm{c}}$ & $73.07^{\mathrm{c}}$ & \multirow{2}{*}{$\mathrm{P}=0.000^{*}$} \\
\cline { 1 - 5 } SD & 3.47 & 4.62 & 6.38 & 0.74 & \\
\hline
\end{tabular}

* Significant at $P \leq 0.05$, different superscripts are statistically significantly different

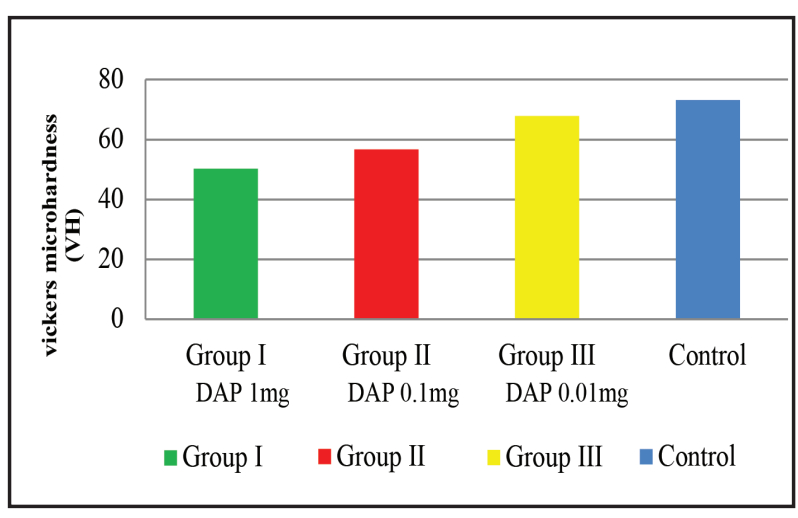

Figure (2): Bar chart showing the impact of different concentrations of DAP on microhardness of radicular dentin comparing with control group.

\section{Fracture resistance:}

A NOVA test showed that there was statistically significant difference among different concentrations of DAP ( $\leq 0.05$ ), group III (DAP $0.01 \mathrm{mg} / \mathrm{ml}$ ) showing the highest mean value of fracture resistance $(684.21 \mathrm{~N})$ comparing to the other group I $(410.37 \mathrm{~N})$ and group II $(461.44 \mathrm{~N})$. Post hoc Tukey test revealed that group III (DAP $0.01 \mathrm{mg} / \mathrm{ml}$ ) showing no statistically significant difference with control group while group I (DAP $1 \mathrm{mg} / \mathrm{ml}$ ) showing statistically significant difference with control group but group II ( DAP $0.1 \mathrm{mg} / \mathrm{ml}$ ) was not statistically significant to group I or group III Table (2) \& (Fig3) . 
Table (2): Descriptive analysis showing fracture resistance among studied groups.

\begin{tabular}{|c|c|c|c|c|c|}
\hline $\begin{array}{c}\text { Statistica } \\
\text { parameters }\end{array}$ & $\begin{array}{c}\text { Group I } \\
(1 \mathrm{mg})\end{array}$ & $\begin{array}{c}\text { Group II } \\
(0.1 \mathrm{mg})\end{array}$ & $\begin{array}{c}\text { Group III } \\
(0.01 \mathrm{mg})\end{array}$ & Control group & Significance test \\
\hline Mean & $410.37^{\mathrm{a}}$ & $461.44^{\mathrm{ab}}$ & $684.21^{\mathrm{b}}$ & $699.04^{\mathrm{b}}$ & \multirow{2}{*}{$\mathrm{P}=0.007^{*}$} \\
\hline SD & 100.96 & 166.41 & 239.69 & 174.66 & \\
\hline
\end{tabular}

* Significant at $P \leq 0.05$, different superscripts are statistically significantly different

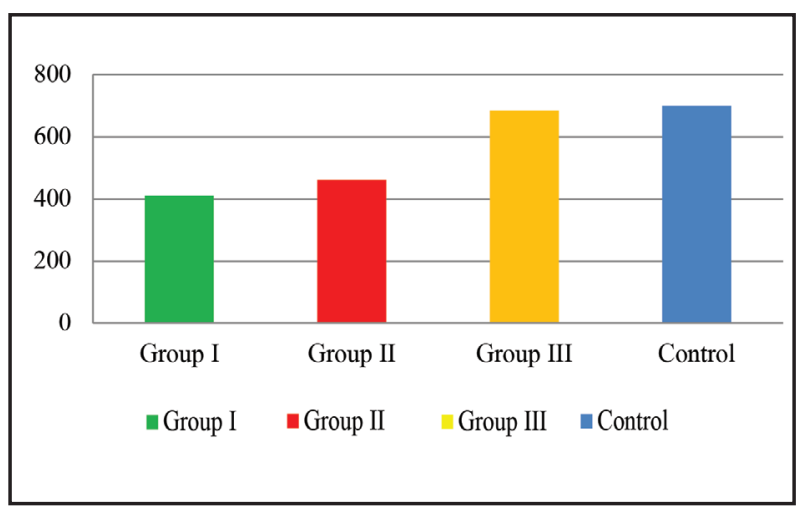

Figure 3: Bar chart showing the impact of different concentrations of DAP on fracture resistance of radicular dentin comparing with control group

\section{DISCUSSION}

Disinfection, removing all microorganism and provide three dimensions seal that achieved by chemo -mechanical preparation of root canal are the main goal of endodontic therapy ${ }^{(12)}$. Revascularization procedure is recommended in immature teeth to increase length and width of root. Because little or no shaping is suggested in treatment of teeth with open apex due to the complexity of root anatomy thin, fins and blunder buss apex ${ }^{(13)}$, to overcome this problem using of intracanal medication is mandatory in revascularization procedures. Triple antibiotic paste is the first choice as intracanal medicament that composed of ciprocin, flagyl and tetracycline ${ }^{(14)}$. Due to discoloration effect of tetracycline, triple antibiotic was replaced with double antibiotic ${ }^{(15)}$.

Higher concentration of double antibiotic has higher antimicrobial effect but on the other hand have a cytotoxic effect on undifferentiated mesenchymal cells in periapical region ${ }^{(16)}$. Previous investigations showed that $(10-100 \mathrm{mg} / \mathrm{ml})$ of triple antibiotic paste made less than $20 \%$ of viable stem cells however using( $1 \mathrm{mg} / \mathrm{ml}$ )concentration $33-56 \%$ of undifferentiated cells still feasible and only at concentrations of $(0.1-0.01 \mathrm{mg} / \mathrm{ml})$ all stem cells of apical papillae still vital without change. Therefore, using lower concentration of DAP has been recommended to overcome this cytotoxic effect $^{(17)}$.

Furthermore, these lower concentrations of DAP were also noticed to be efficient against endodontic micro-organisms ${ }^{(18)}$. Although, the suggested low concentrations (1- $0.1-0.01 \mathrm{mg} / \mathrm{ml}$ ) of DAP as in this study are in liquid form, which makes its usage difficult ${ }^{(19)}$. Thus, methylcellulose was applied as thickening agent that added to different concentrations of double antibiotics to obtain a clinical useable consistency and increase duration of therapeutic agent ${ }^{(20)}$.

Intracanal medication used in regenerative procedures adversely effect on the chemical, physical and mechanical properties of radicular dentin $^{(21)}$. Objective studies have been recorded that the increasing of root wall thickness of teeth with open apices after regenerative procedure is only for middle and apical part of the root but the region cervically is the most area that prone to fracture in treated teeth with open apices ${ }^{(22)}$. So, it is necessary to decrease the effect of these medicaments on the already weak area of teeth with open apex. 
Dentin has been consisted of its organic and inorganic components, calcium $(\mathrm{Ca})$ and phosphorus (P) present in hydroxyl apatite crystals are the major inorganic components of dental hard tissue ${ }^{(23)}$. The strength of dentin is located by the bond between hydroxyl apatite and collagen fibers. Exposure of root dentin to the root canal medicaments was shown to affect its physical properties and subsequently affect fracture resistance ${ }^{(24)}$. Therefore, the key of using DAP depend on its ability to remove microorganism and on the other hand doesn't affect mechanical and physical properties of root dentin or damage the stem cells.

In the current study, the highest concentration of DAP in group I $(1 \mathrm{mg} / \mathrm{ml})$ initiated a significant reduction in microhardness and fracture resistance of root specimens compared to other groups. This could be clarified by demineralizing effect of these acidic antibiotic combinations at higher concentrations ${ }^{(25)}$.A lately available study has also concluded that $1 \mathrm{~g}$ TAP caused a significant microhardness reduction of radicular dentin at 500 micron from pulp-dentin interface compared to (1mg) TAP ${ }^{(26)}$. The lowest concentration of DAP in group III $(0.01 \mathrm{mg} / \mathrm{ml})$ showed no significant difference in microhardness and fracture resistance compared to untreated control group. Lower concentration of DAP $(0.01 \mathrm{mg} / \mathrm{ml})$ was used in this study to decrease the unnecessary effect of higher concentration of DAP on the mechanical and chemical properties of radicular dentin. DAP with lower concentration was also found to be efficient against various endodontic pathogens ${ }^{(27)}$.

Instrumentation isn't recommended in revascularization procedure but it is performed in the current research in order to standardize the dimension of roots before the recommended tests.

\section{CONCLUSION}

Higher concentration of double antibiotic $(1, \quad 0.1 \mathrm{mg} / \mathrm{ml})$ decreased microhardness and fracture resistance of root dentin, while lower concentration of double antibiotics $(0.01 \mathrm{mg} / \mathrm{ml})$ had no or minimal consequence on microhardness and fracture resistance of radicular dentin in revascularization procedures.

\section{REFERENCES}

1. Ordinola ZR, Bramante CM , Minotti PG , Cavenago BC, Garcia RB , Taur Swapnil, et al . Anti-microbial activity of triple antibiotic paste, $2 \%$ chlorhexidine gel, and calcium hydroxide on an intraoral-infected dentin biofilm model. J Endod .2013; 39:115-18.

2. Mohamed SE, El-Hady SA. Development of an intra-canal mature biofilm and its susceptibility to some anti-microbial intra- canal medications: an in vitro study. Eur j Dent .2012; 6:43-50.

3. Jeeruphan T, Jantarat J, Yanpiset K, SuwannapanL, Khewsawai P, Hargreaves KM. Comparison of radiographic and survival outcomes of immature teeth treated with either regenerative endodontic or apexification methods: A retrospective study. J Endod .2012; 38:1330-6.

4. Zarei M, Afkhami F, Malek Poor Z. Fracture resistance of human root dentin exposed to calcium hydroxid inter visit medication at various time periods: an in vitro study. Dent Traumatol. 2013; 29:156-60.

5. Diogenes A, Henry MA, Teixeira FB, Hargreaves KM. An update on clinical regenerative endodontics. Endod Top. $2013 ; 28: 2-3$.

6. Prather BT, Ehrlich Y, Spolnik K, Platt JA, Yassen GH. Effects of two combinations of triple antibiotic paste used in endodontic regeneration on root micro hardness and chemical structure of radicular dentine. J Oral Sci .2012; 56: $245-51$.

7. Shin SY, Albert JS, Mortman RE. One step pulp revascularization treatment of an immature permanent tooth with chronic apical abscess: a case report. Int Endod J .2009; 42: 1118-26.

8. Fouad AF. The microbial challenge to pulp regeneration. Adv Dent Res 2012; 23: 285-9.

9. Yassen GH, Chu TM, Gallant MA, Allen MR, Vail MM, Murray PE et al. A novel approach to evaluate the effect of medicaments used in endodontic regeneration on root canal surface indentation. Clin Oral Investig. 2014; 18: 1569-75.

10. Liu WC, Goebel WS, Gregory RL. The effect of diluted triple and double antibiotic pastes on dental pulp stem cells and established Enterococcus Faecalis biofilm. Clin Oral Investing.2015; 19:2059-66. 
11. Lenzi R, Trope M .Revitalization procedures in two traumatized incisors with different biological outcomes. Journal of Endodontics. 2014; 38:411- 4.

12. Ari H, Erdemir A, Belli S. Evaluation of the effect of endodontic irrigation solution on the microhardness and the roughness of root canal dentin. J Endod.2008; 30:792-5.

13. Hülsmann $M$.Effects of mechanical instrumentation and chemical irrigation on the root canal dentin and surrounding tissues. Endod Top .2013; 29: 55-86.

14. Hosino E, Kurihara-Ando N, Sato I. In vitro antimicrobial susceptibility of bacteria taken from infected root dentine to a mixture of ciprofloxacin, metronidazole, and minocycline. Int Endod. 1996 ;29: 125-30.

15. Trope M .Treatment of the immature tooth with a nonvital pulp and apical periodontitis. Dental Clinics of North America. 2010; 54: 313-24.

16. Althumairy RI, Teixeira FB, DiogenesA .Effect of dentin conditioning with intracanal medicaments on survival of stem cells of the apical papilla. J Endod. 2014; 40: 521-5.

17. Mohamed F R. Evaluation of antimicrobial effects of different concentrations of triple antibiotic paste on mature biofilm of Enterococcus faecalis .J Dent Res. 2015; 93:138-43.

18. Berkhoff JA, Chen PB, Teixeira FB, Diogenes A. Evaluation of triple antibiotic paste removal by different irrigation procedures. J Endod. 2016; 40:1172-7.

19. Yassen GH,Eckert GJ, Platt JA. Effect of intracanal medicaments used in endodontic regeneration procedures on microhardness and chemical structure of dentin. Restor Dent Endod .2015;40:104-12.
20. Li Cl, Martini LG, Ford JL, Roberts M. The use of hyperomellose in oral drug delivery. J Pharm Pharmacol 2005; 57: 533-46.

21. Hülsmann M . Effects of mechanical instrumentation and chemical irrigation on the root canal dentin and surrounding tissues. Endod Top. 2013; 29: 55-86

22. Bose R, Nummikoski P, Hargreaves K. A retrospective evaluation of radiographic outcomes in immature teeth with necrotic root canal systems treated with regenerative endodontic procedures. J Endod 2009; 35: 1343-9.

23. Cohen M, Garnick JJ, Ringle RD. Calcium and phosphorus content of root exposed to the oral environment. J Clin Periodontol .1992; 19: 268-73

24. Zarei M, Afkhami F, Malek Poor Z. Fracture resistance of human root dentin exposed to calcium hydroxide intervisit medication at various time periods: an in vitro study. Dent Traumatol. 2013; 29:156-60

25. Yassen GH, Chu TM, Eckert G, Platt JA .Effect of medicaments used in endodontic regeneration technique on the chemical structure of human immature radicular dentin: An in vitro study. J Endod.2013; 39:269 -73.

26. Blake T Prather, Ygal Ehrlich, Kenneth Spolnik. Effect of two combinations of triple antibiotic paste on root microhardness and chemical structure of radicular dentine. J Oral Sci.2014; 56:245-51.

27. Sabrah AH, Yassen GH, Gregory RL. Effectiveness of antibiotic medicaments against biofilm formation of Enterococcus faecalis and Porphyromonas gingivalis. J Endod .2013; 39:1385-9. 